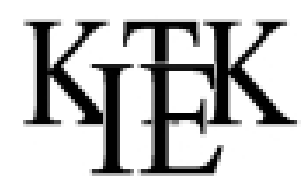

MÜHELYTANULMÁNYOK

ÚJ SOROZAT
INSTITUTE OF ECONOMICS

HUNGARIAN ACADEMY OF SCIENCES

$$
\text { MT-DP. 2003/5 }
$$

NEW SERIES

DISCUSSION PAPERS

\title{
COMMON CURRENCY, COMMON MARKET?
}

\author{
RICHARD FRIBERG
}

Institute of Economics

Hungarian Academy of Sciences

Budapest 


\section{COMMON CURRENCY, COMMON MARKET?}

RICHARD FRIBERG 
KTK/IE Discussion Papers 2003/5

Institute of Economics Hungarian Academy of Sciences

KTK/IE Discussion Papers are circulated to promote discussion and provoque comments. Any references to discussion papers should clearly state that the paper is preliminary. Materials published in this series may subject to further publication.

\section{Common Currency, Common Market?}

Author: Richard FRIBERG, assistant professor. Stockholm School of Economics, P.O.Box 6501, SE-113 83 Stockholm, Sweden.

Phone: (+46-8) 736-9602 Fax: (+46-8) 31-3207 E-mail: nerf@hhs.se

Published by the Institute of Economics Hungarian Academy of Sciences, Budapest, 2002. 


\title{
COMmon CurRency, COMMON MARKeT?
}

BY RICHARD FRIBERG

\begin{abstract}
Does the common currency promote goods market integration within the EMU? We argue that such an effect is likely, but that the mechanism typically proposed - lover costs of arbitrage because of increased price transparency - is likely to be of minor importance. Instead we sketch a duopoly model which stresses that lover possibility of future real exchange rate variability lowers the option value of being able to price discriminate. The euro would promote market integration because it is less valuable for firms to segment markets. In addition we argue that fairness concerns and less risk associated with third party arbitrage may be potentially important.
\end{abstract}

Keywords: exchange rate pass-through; law of one price; EMU; price discrimination; price transparency; real options

JEL Classification: F13; F15; F41; L40

RICHARD FRIBERG

KöZÖS PÉNZ, KÖZÖS PIAC?

Összefoglaló

Igaz-e az, hogy a közös valuta bevezetése az európai gazdasági és pénzügyi unió országaiban elösegíti a termékpiacok integrációját? A tanulmány megmutatja, hogy egy ilyen hatás valószinü, de a legtöbbet hangoztatott mechanizmus - az árak könnyebb összehasonlithatóságából fakadó arbitrázs költség csökkenés - minden bizonnyal csak kis szerepet játszik majd. A tanulmány felvázol egy duopol piaci modellt, amely azt hangsúlyozza, hogy a kisebb várható jövőbeni árfolyam-változékonyság csökkenti az árdiszkrimináció lehetöségének opciós értékét. Az euró azért segiti elö a piacok integrációját, mert ezután a cégeknek kevésbé lesz érdemes szegmentálniuk a piacokat. A fentiek mellett a tanulmány megmutatja, hogy a méltányossági megfontolások, illetve a harmadik fél által végzett arbitrázzsal kapcsolatos kisebb kockázat szerepe is potenciálisan fontos lehet. 


\section{INTRODUCTION}

Euro notes and coins have now replaced the national currency in the EMU. Will this be a catalyst in creating a common market in the EMU area? According to the European Commission and many practitioners the answer is yes. The mechanism is typically argued to be increased price transparency.

An example of this reasoning is The Economist (2001) which state that "the greater transparency the single currency brings to prices will make a big difference to the way business is conducted. Simple economic theory suggests that savvy consumers will look across European markets and note where the price of a good or service is lowest. They will then either purchase the good or service there, conducting a form of what economists call "arbitrage"; or they will use the information to prevail upon their more expensive local provider to bring the price down... In the past, manufacturers have been able to maintain price differentials because their customers found it difficult to compare prices. With the euro, it will become much easier [to compare prices]."

Many economists are uncomfortable with this emphasis on transparency. Do potential arbitrageurs really find it so difficult to compare prices that is matters for why prices of typical consumer goods differ across Europe? Rather, a common view among economists is that prices differ because costs, demand patterns and the strength of competition vary across countries and price differentials need to become very large before they dominate the costs associated with arbitrage of consignor goods.

This paper analyses the lessons of recent research for the impact a common currency on market integration. We show how the latter view can be reconciled with a market integrating effect of a common currency. We first document that many goods markets are segmented along national borders and trade costs create a band of inaction within relative prices can move without triggering arbitrage. The following section examines how a common currency might narrow that band. We proceed to analysis of endogenous market segmentation, how might a common currency affect the incentives to create a band of inaction? 


\section{EMPIRICAL EVIDENCE ON SEGMENTATION OF MARKETS ALONG NATIONAL BORDERS}

In a tradition that originates with Cournot and Marshall we define a market as an area within which prices rapidly converge to equality, correcting for costs of transportation. If prices were much lower in one location it would pay for an arbitrageur to buy it there and resell in the high price region. Indeed, for many commodities traded on exchanges, such as gold, arbitrage rapidly eliminates any price differences over and above transport costs. However, for consumer goods the stylised fact seems to be that price differentials across markets diminish at a "surprisingly" slow rate. ${ }^{1}$ In an influential paper Engel and Rogers (1996) show that for two cities to be on opposite sides of the US-Canadian border adds as much variability in relative prices of narrowly defined price indexes as if the cities were 75000 miles apart. The main conclusion is that both distance and the border matter - and that the border effect is very large. Engel and Rogers (2001) examine European data, again finding a huge border effect. Prices that are sticky in the currency of consumers coupled with exchange rate variability are an important explanation for this border effect. We can express the price difference between markets as

$$
p-e p^{*}
$$

where is $p$ is the price in the Home country, $p^{*}$ the foreign price and $e$ the current exchange rate. Given that the median interval of price changes is yearly (Taylor, 1999) it is clear that a common currency will lead to less relative price variability since $e$ then will be stable.

Exchange rate variability alone can not explain the border effect however, there must also be some barriers to arbitrage. The lower these barriers are, the narrower is the band of inaction within which relative prices can move without triggering arbitrage. Transport costs and various formal and informal trade barriers are obvious candidates. These barriers are large for many goods - also within the EU. Evidence of market segmentation comes from detailed industry studies (such as Goldberg and Verboven's, 2001, study of European car markets or Haskel and Wolf's, 2001, study of prices at the furniture retailer IKEA), from studies of large data sets on prices of the

\footnotetext{
${ }^{1}$ See Rogof (1996) for a survey and Taylor (2001) for a methodological discussion.
} 
same or similar goods in different markets (such a Crucini et al's, 2001, analysis of Eurostat data Rogers et al, 2001 of data from the Economist Intelligence Unit), from antitrust cases (with the classic case of United Brands v. Commission, 1978 (bananas) and the blocked merger between truck makers Volvo and Scania as but two examples) and from studies of trade flows (see Head and Mayer, 2000 and Anderson and Van Wincoop, 2001 for a methodological discussion). To some extent the results conform to economic intuition - deviations tend to be lower if goods can be characterised as traded or have a large proportion of traded inputs (Crucini et al, 2001) and European price differentials have decreased during the 19902 , as expected after the "1992" program to remove remaining barriers to the free flow of gods within the EU (Rogers et al, 2001). There is preciously little empirical evidence on the relative importance of various barriers and it is probably fair to say that the sources of market segmentation in Europe remain somewhat of a mystery. Can a common currency be an important barrier?

\section{WHY A COMMON CURRENCY CAN NARROW THE BAND OF INACTION}

There are two ways through which arbitrage of consumer products can take place - either consumers themselves buy the product in the cheaper location or a third party does so and resells it. It is beyond doubt that individuals find it easier to compare two prices that are expressed in the same currency, the question is if we believe this to be quantitatively important - an issue that can only be settled by empirical work. In Asplund and Friberg (2001) we make use of a "natural experiment" and examine the pricing in three Scandinavian duty-free shops. In these, each good has price tags is several currencies. We thus examine deviations from the law of one price for identical goods at the same location and time and with full information about prices. The question about the relative importance of different barriers is then easy because there is only one barrier - price setting in different currencies. There are indeed non-trivial deviations from the law of one price - up to 15 percent. Figure 1 illustrates the deviations from the law of one price 1 litre of Smirnoff vodka in the on-board duty-free shops of the Viking Line ferries that connect Sweden and Finland. We also plot the bands of inaction created by costs of exchanging currency in the on-board exchange is done on shore (or using credit card).

It appears that costs of exchanging currency on-board are an important barrier in this setting, the band of inaction created is sizeable and deviations that are outside these barriers are short lived. Transparency also matters 


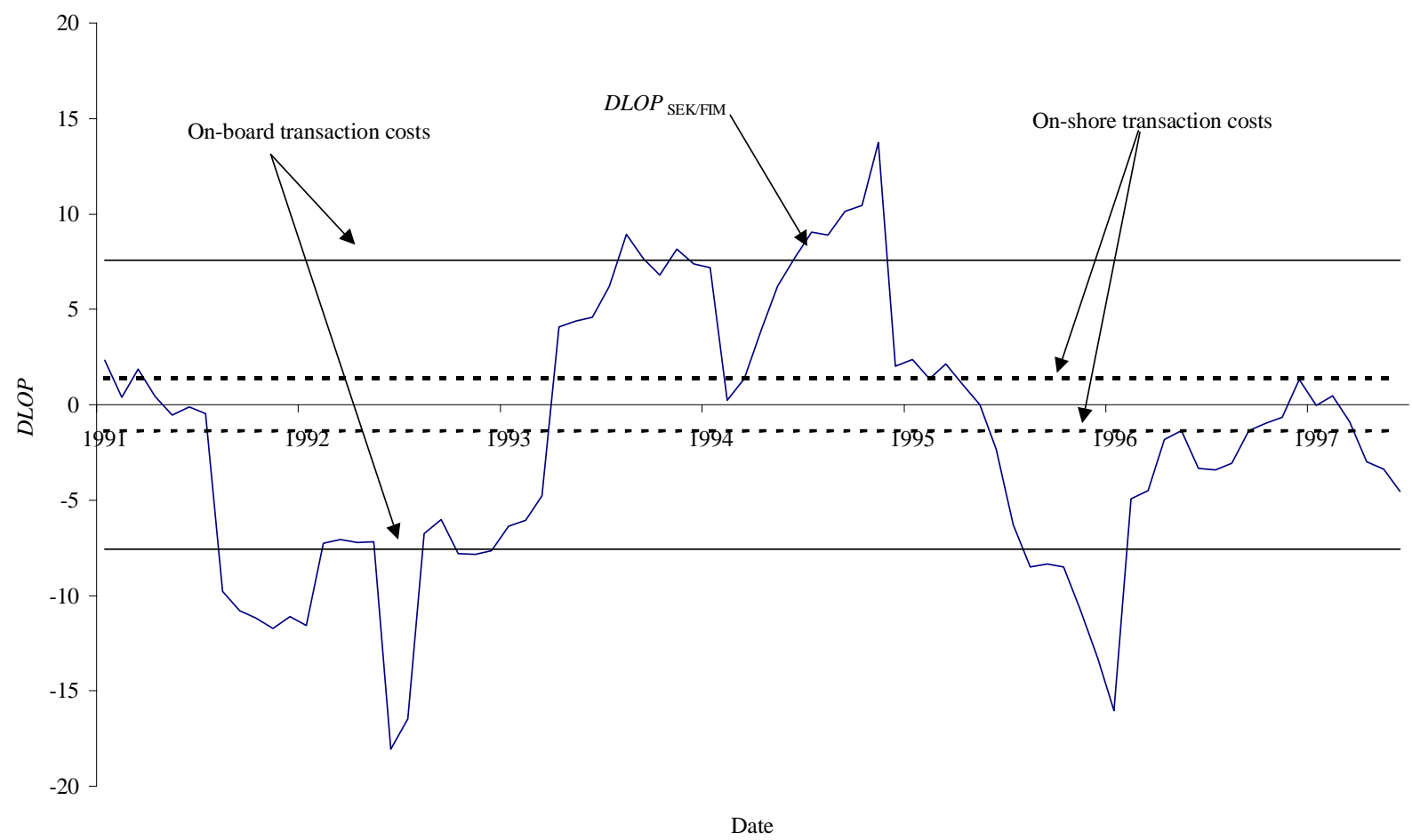

Fig 1. Deviation from the law of one price for 1 liter Smirnoff Vodka, Viking Line on board duty-free shop. 
however, the costs of exchanging on shore or using a credit card in the other currency quite narrow bounds and the deviation is almost always outside this band. A common currency here would have implied a much tighter hold of the law of one price and in this sense the results confirm that a common currency greatly reduces relative price variability compared to a benchmark of a floating exchange rate.

However, these data do not give much support to the idea that pricing in different currencies is an important explanation for price discrimination across national borders for other consumer goods. Firstly, in the duty-free shops the average deviation from the law of one price is small for most goods and often not statistically significant from 0 . Sometimes it is cheaper in Finnish markka and sometimes in Swedish kronor. Secondly, since the cognitive costs of comparing prices should be independent of the prices of goods (it should be no more difficult to compare 10 Euros to 10 US dollars than 1000 Euros to 1000 US dollars) rule-of-thumb behaviour predicts more narrow bounds on big-ticket items or goods that are bought frequently. Since big-ticket items are typically the only ones for which it is profitable for a single consumer to buy from another country, the duty-free data (on relatively low cost and infrequently bought goods) are likely to present an upper bound on the size of deviations that can be explained by pricing in different currencies.

Two of the duty-free shops mentioned that the main pressure to change prices was customer complaints about the price differentials rather than arbitrage. Also in other cases this is likely to be an important channel for market integration. For instance, when the magazine The Economist moves to a common Euro cover price it is hard to imagine that arbitrage by consumers is a concern. However it is well established from experimental work that consumers care about fairness (see e.g. Rabin, 2002, for a discussion). Long-term relations between firms and customers are the norm (see e.g. Blinder et al, 1998) and buyers are likely to be sensitive to what they may see as sellers taking advantage of them by "unfair" pricing practises. Customers may not be sufficiently interested in fairness to calculate common currency price differentials and in any case you need a time series to see price differentials are the outcome of attempts at price discrimination (which may be seen as unfair) rather than just being a by-product of exchange rate variability coupled with sticky prices. In contrast, when prices are expressed in the same currency, price differentials are immediately obvious. Price discrimination is a common practice - it appears that people are not upset by for instance discounts to low income groups. How- 
ever, some introspection yields that individuals are less liable to oversee price discrimination on national grounds - think of a restaurant that charges based on what passport you have. It is hard to know how much this will matter quantitatively - for publicly posted prices of goods distributed by the manufacturer and where there are low possibilities of arguing that marginal cost differences are the explanation for price differences it may be of substantial importance in equalising posted prices. Note that so far there appears little that can be archived by a common currency that a perfectly fixed exchange rate couldn't bring about.

The other channel through which a common currency might affect market integration is through arbitrage conducted by third parties. Transparency and fairness should matter little here - rather costs related to distribution are likely to be a main barrier to arbitrage. ${ }^{2}$ Even though EU case law gives substantial rights to arbitrageurs, vertical integration (or vertical restrains such as exclusive territories) remains an important barrier to arbitrage. Take the furniture retailer IKEA as an example, IKEA retails only through their own stores. Arbitrageurs would have to buy at retail prices in another country and in all likelihood have to sell at a substantial rebate in order to induce consumers to buy from them, rather than from IKEA. One reason for such a rebate is that counterfeits and damaged goods appear common in third party arbitrage - the possibility that the good is inferior quality obviously raises the price differential needed for arbitrage to be profitable. A common currency may have a market integrating effect since increased stability of relative prices is likely to increase the incentives to invest, in reputation and distribution channels, for risk averse or liquidity constrained arbitrageurs. Lastly, a number of papers by Andrew Rose, for instance Glick and Rose (2002) find that a common currency promotes trade. It is hard to know how relevant this evidence is for EMU countries and we learn little about the mechanisms. Nevertheless, it takes no great leap of

${ }^{2}$ There is little empiricalevidence on the extent and price impact of parallel imports, as stressed by Obstfeld and Rogoff (2000) our profession has focused to much on consumer arbitrage. One exception is Ganslandt and Maskus (2001) who examine the natural experiment of when Sweden opened up for parallel imports of pharmaceutical products, indeed finding substantial price effects. An important element of this case was that the parallel importers had access to the same outlets (state owned pharmaceutical monopoly) as the goods that went through the regular channel. 
faith to believe that, if a common currency promotes trade in general, it also facilitates trade in secondary markets.

\section{ENDOGENOUS SEGMENTATION}

Many of the barriers that segment markets are endogenous - restrictions in parallel imports, different brand names and product specifications in different countries as vell as far reaching vertical restrains exist because of deliberate choices by firms, as a reading of the EU antitrust cases will make clear. How are such choices affected by a common currency? In Friberg (2001) I show how lower expected real exchange rate variability leads to market integration by firms. The intuition is that third degree price discrimination is profitable when the optimal prices to two consumer groups differ. Except in very specific cases (notably constant elastic demand) real exchange rate changes will affect the relation between the optimal prices on two markets. Large swings in the real exchange rate between two similar markets thus create incentives for market segmentation. The more variability, the more valuable will it be to segment and "price-tomarket". If a common currency takes away the possibility of large future swings in the real exchange rate, it consequently takes away much of the incentive for market segmentation. For instance, as the pound has appreciated against the euro, cars have become substantially more expensive in Britain than in continental Europe. Clearly, in a period of a strong pound it has been valuable to be able to have a different price in the UK than on the continent.

To make the intuition more precise let us sketch a simple duopoly extension of the model in Fiberg (2001). The setup is related to Friberg and Martensen (2001) where we model a Cournot duopoly and examine how the incentives to segment markets depend on transport costs between those markets. ${ }^{3}$ The mechanism of interest is how the possibility of exchange rate swings affect the expected benefits of segmenting markets - should the firms for instance invest in different brand names and product specifi-

\footnotetext{
${ }^{3}$ While the link between exchange rate variability and the decision to segment is new, there are a number of related literatures. In particular we relate to work on price discrimination under competition (see for instance Corts, 1998), sptial pricing strategies (Thisse and Vives, 1988) and „,segmented markets” models in international economics (Brander and Krugman, 1983 and much subsequent work).
} 
cations in the different markets, and thereby have a greater possibility to price discriminate?

Consider two firms, one based in France and one in Italy. The model is a simple partial equilibrium model of "reciprocal markets" - both firms sell on both markets. The timing is assumed to be 1) firms simultaneously decide on whether to segment, 2) the exchange rate is revealed, 3) prices are set and profits are realised. To keep issues as simple as possible assume that the costs of segmenting are fixed: $K^{l}$ and $K^{F}$ respectively. It a firm has taken the cost of segmenting markets is sets prices on both markets without constraint whereas if it has not segmented, it optimises subject to a constraint that the price if its good should be equal in France and Italy. The exchange rate between the two countries is given by $e$, expressed as the Italian lira price of French francs. There is no direct effect of Exchange rate on demand or costs and we can thus view changes in $e$ as real exchange rate changes.

Using a star to denote prices in France, $p$ and $p^{*}$ are the Italian firm's prices, and $P$ and $P^{*}$ the French firm's corresponding prices in Italy and France. Let $c$ be the constant marginal costs, which are equal for both firms. Let $\lambda$ and $\mu$ be Langrange multipliers that will be set equal to 0 for a firm that has taken the fixed cost of segmenting in a previous period. Assume that demand takes the simple linear form associated with Bowley (see Martin, 2001) such that $a$ and $b$ are positive constants and $\theta \in(0,1)$ measures the degree of product differentiation. Assuming that firms compete in prices, the Italian firm's profit maximisation problem in stage 3, including the constraint becomes

$\mathrm{II}^{I}=\max _{p, p^{*}}(\mathrm{p}-\mathrm{c})\left(\frac{(1-\theta) a-p+\theta P}{\left(1-\theta^{2}\right) b}\right)+\left(e p^{*}-c\right)\left(\frac{(1-\theta) a-p^{*}+\theta P^{*}}{\left(1-\theta^{2}\right) b}\right)-\lambda\left(p-e p^{*}\right)$,

and the French firm's problem is

$\mathrm{II}^{I}=\max _{P, P^{*}}\left(\frac{P}{e}-\mathrm{c}\right)\left(\frac{(1-\theta) a-P+\theta p}{\left(1-\theta^{2}\right) b}\right)+\left(P^{*}-c\right)\left(\frac{(1-\theta) a-P^{*}+\theta p}{\left(1-\theta^{2}\right) b}\right)-\mu\left(P^{*}-e P\right)$.

If optimal prices differ across markets, the constraints will be binding and the Langrange multipliers positive. We examine the Nash (Bertrand) equilibria in prices, such that each firm conjectures a zero response to changes in its own prices. Solving the system of equations yielded by the four first order conditions for profit maximisation and the relevant Langrange conditions gives us optimal prices as a function of the exchange rate. 
Let us focus on how profits depend on the exchange rate in stage 3, knowledge of this will determine choices in stage 1. Figure 2 plots how the difference in profits between different strategies (excluding the fixed cost) for the Italian firm depend on the exchange rate. In this plot we have set $\gamma=$ $0.8, a=4, b=1$ and $c=0.2$.

The upper solid line in 2 represents the increase in profits for the Italian firm if both firms segment compared to the case where both integrate. Clearly unconstrained profits are always higher than when prices are constrained to be equal across markets. The dotted line represents the increase in profits for the Italian firm when segments but the French firm integrates, compared to the case where both integrate. A number of points can be seen from this very stylised framework. The first and obvious is that when the exchange rate is equal to 1 there is no value of segmenting the markets, we then have two markets with the same optimal price. However, as soon as the exchange rate differs from 1 it is valuable to segment markets. Say for instance that the fixed cost of segmenting is 0.04 , the Italian firm would then want to segment if $e<0.761$ or $e>1.271$, as long as the French firm segments as well. The gain in profits from segmenting would then outweigh the cost - given a sufficiently high probability that the exchange rate will be outside these bounds in period 3, a firm will thus want to segment in period 1. This leads us our second and main result; holding $E(e)=1$, making the tails of the exchange rate distribution thinner, lowers the expected value of being able to segment. If we are in an equilibrium where both firms segment, a concentration of the probability mass to $e=1$ lead firms to integrate. The intuition is simple, by segmenting is stage 1 each firm effectively buys an option to different prices across markets in stage 3 . The lower the probability that the firm will want to exercise that option, the less is the firm willing to pay to segment markets. A monetary union differs from a fixed exchange rate in that the probability of future exchange rate realignments is much lower, if not 0 . A monetary union thus gives incentives for a firm to adjust its total strategy with respect to marketing, distribution, warranties and service networks in a way that a fixed, but adjustable, exchange rate does not. This is consistent with Parsley and Wei's (2001) examination of prices collected by the Economic Intelligence Unit. They find that currency unions are associated with much greater goods market integration than just a fixed exchange rate arrangement.

A third important result is that the benefit of segmenting depends on what the other firm does, if the French firm integrates the gain of segmenting for the Italian firm is lower. Interpreting this more broadly implies that integrating by one firm may set off a chain reaction whereby other firms inte- 


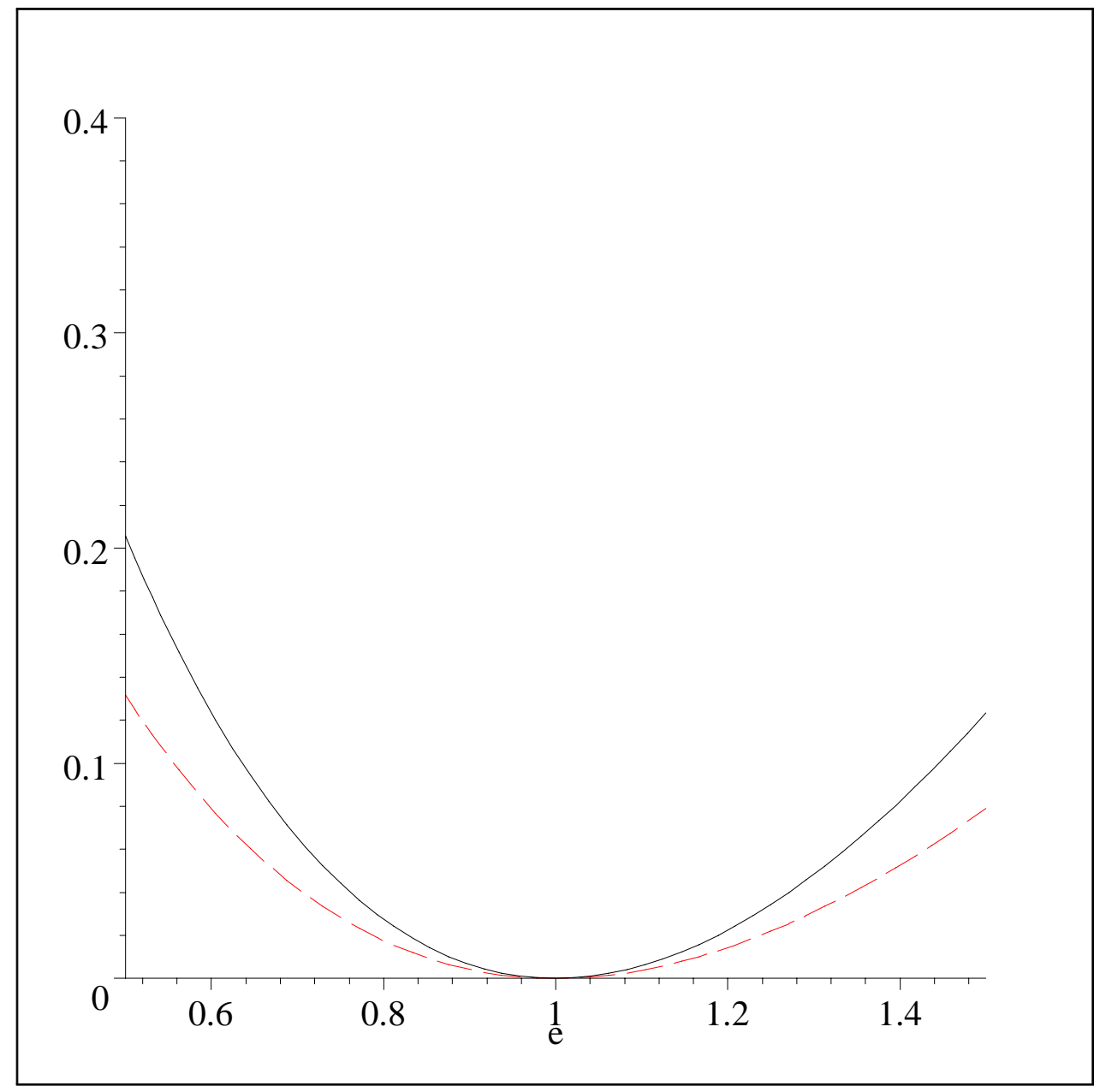

Fig. 2. Gain in profits for Italian firm of segmenting (as a function of the exchange rate). 
grate as well. Catalysts are likely to be firms that have a relatively high cost of segmenting - think for instance of a new entrant, should it establish separate brands and distribution networks for the different countries in Europe or should it use the same brand name everywhere $?^{4}$ Many results in studies of international oligopoly hinge on whether firms regard their products as strategic substitutes or strategic complements (as they are in our example). ${ }^{5}$ That is not true in this case. We are assuming that both firms choose to segment/integrate simultaneously and there is no room for strategic effects related to first mover (dis)advantages. While equilibrium prices and quantities will depend on the form of competition (price competition is more fierce) the result that integrating has a negative effect on the other firm survives also under quantity competition (which in our setting implies that products are strategic substitutes). If the competitor has the same price on the two markets this squeezes the optimal price differential for the Italian firm and the gain from price discriminating is lower.

The framework is simple and easily adapted to examining differences in marginal costs or in the parameters of the demand functions across countries. Other factors promoting market integration in the EU can be analysed in the setup - tax harmonisation, reductions in income differentials and common media channels will all tend to promote price equalisation by making optimal prices more equal. Harmonisation of technical standards, community exhaustion of trademarks (see for instance Silhouette v. Hartlauer for a recent important case) and an aggressive stance by the Competition Directorate General on market segmentation (see for instance commission v. Volkswagen, DaimlerChrysler or JCB for recent cases) all tend to make it more costly to segment markets along national lines.

4 Work on oligopolistic price discrimination finds a strong tendency for price discrimination (Corts, 1998 and Thisse and Vives, 1988). We find the same if we, as ios customary in that literature, assume that there are no direct costs of segmentation.

${ }^{5}$ The prime example of this is the case of strategic trade policy, the optimal policy is a subsidy to the national producer in the case of strategic substitutes (Cournot competition between substitutes) but a tax on the national producer in the case of strategic complements (Bertrand competition between imperfect substitutes). See Eaton and Grossman (1986). 


\section{DISCUSSION}

We have examined the mechanisms by which a common currency can promote market, arguing that more effective arbitrage due to increased transparency is likely to be of minor importance but other mechanisms such as endogenous segmentation my have a substantial impact. In practice market integration may mean moving to a single retail (or wholesale) price across Europe and use of the same brand name, product characteristics and post-sale service. Lower incentives for endogenous segmentation are consistent with the recent practices of manufactures of consumer products such as Unilever, Danone or Nestlé to concentrate on fewer brand names and increasingly put the parent brand name on the product. It goes without saying that there is no reason to believe that the EMU area will become a common market for a goods. Some markets will remain exogenously segmented, and for others the gains from price discrimination are sufficiently large for endogenous segmentation to be profitable, also under a common currency. Nevertheless, the analysis in this paper suggests that the will see a move towards market integration and decreased importance of national borders for many types of traded good markets. ${ }^{6}$

An important insight from the literature on Pricing-to-Market and the new open economy macroeconomics is that the exchange rate can fluctuate so much in part because it "matters so little". National goods market are segmented and exchange rate changes are not fully passed through into prices, thus to some extent insulating the real economy from the effects of exchange rate fluctuations. While a general equilibrium modelling of endogenous market segmentation remains far outside the scope of the present article it may be worth to point out the feedback effect that endogenous segmentation implies. The more the real exchange rate fluctuates, the more is it worth for firms to be able to segment markets and the more will they try to do so; in this sense pricing-to-market will lead to even more pricing-

${ }^{6}$ To say that a common curreny promotes market integration is not necessarily to say that all consumers will face the same price. Let us again use The Economist as an example. They have a common cover price in euros, but clearly most of their revenues come from subscriptions where different forms of rebates abound depending on work status (student rebates) and subscription history. Thus while we believe that a monetary union promotes market integration - i.e. we will see less of third degree price discrimination across national borders - we might well get an increased use of other forms of price discrimination. 
to-market. We leave the development of these ideas for future research. This paper has tried to make a simple point; a monetary union is likely to be decisive channel.

\section{ACKNOWLEDGMENTS}

The author is grateful to the Wallander and Hedelius foundation, the Swedish Competition Authority and Stiftelsen Siamon for financial support. This paper was written during a visit to the International Economics Section at Princeton University, which I thank for its hospitality. Thanks to Pierre-Olivier Gourinchas and Thomas Mathä for valuable discussions.

\section{REFERENCES}

Anderson, J., Van Wincoop, E. (2001): Gravity with gravitas: A solution the border puzzle. NBER Working paper 8079.

Asplund, M., Friberg, R. (2001): The law one price in Scandinavian dutyfree stores. American Economic Review 91, 1072-1083.

Blinder, A.S., Canetti, E.D., Lebow, D.E., Rudd, J.B. (1998): Asking about Prices - A New Aproach to Understanding Price Stickiness. Russell Sage Foundation, New York

Brander, J., Krugman, P. (1983): A 'Reciprocal Dumping' Model of International Trade. Journal of International Economics 15, 313-321.

Corts, K. (1998): Third-Degree Price Discrimination in Oligopoly: All-Out Competition and Stategic Commitment. RAND Journal of Economics 29, 306-323.

Crucini, M., Telmer, C., Zachariadis, M. (2001): Understanding European real exchange rates. Manuscript. Vanderbilt University

The Economist, 2001. The common good. The Economist, November 29, 2001.

Eaton, J., Grossman, G.M. (1986): Optimal trade and industrial policy under oligopoly. Quarterly Journal of Economics 101, 383-406.

Engel, C., Rogers, J. (1996): How wide is the border? The American Economic Review 86, 1112-1116.

Engel, C., Rogers, J. (2001): Deviations from purchasing power parity: sources and welfare costs. Journal of International Economics 55, 29-57.

Friberg, R. (2001): Two Monies, Two Markets? Variability and the Option to Segment. Journal of International Economics 55, 317-327. 
Friberg, R., Martensen, K. (2001): Endogenous market segmentation and the law one price. Stockholm School of Economics Working Paper 471.

Ganslandt, M., Maskus, K. (2001): Parallel imports of pharmaceutical products in the European Union. IUI Working paper No 546.

Glick, R., Rose, A.K. (2002): Does a currency union affect trade? The time series evidence. European Economic Review 46, 1125-1551.

Goldberg, P.K., Verboven, F. (2001): Market integration and convergence to the law of one price - Evidence from the European car market. Manuscript. Yale University

Haskel, J., Wolf, H. (2001): The law of one price - a case study. Scandinavian Journal of Economics 103, 545-558.

Head, K., Mayer, T. (2000): Non-Europe: The magnitude and causes of market fragmentation in Europe. Weltwirtschaftliches Archiv 136, 285-314.

Martin, S. (2001): Advanced Industrial Economics. Blackwell Publishers, London (Second Edition)

Obstfeld M., Rogoff, K. (2000): The Six Major Puzzles in International Macroeconomics: Is there a Common Cause? In: Bernanke, B. and Rogof K. (eds.): NBER Macroeconomics manual 2000.

Parsley, D., Wei, S.-J. (2001): Limiting currency volatility to simulate goods market integration: A price based approach. NBER Working paper 8468 .

Rabin, M. (2002): A perspective on psychology and economics. European Economic Review 46, 657-685.

Rogers, J., Hufbauer, G., Wada, E. (2001): Price level convergence and inflation in Europe. Manuscript. Federal Reserve

Rogoff, K. (1996): The purchasing power puzzle. Journal of Economic Literature 34, 647-668.

Taylor, J.B. (1999): Staggered price and wage setting in macroeconomics. In: Taylor, J.B., Woodford, M. (eds.): Handbook of Macroeconomics. Elsevier, Amsterdam, 1009-1050.

Taylor, A.M. (2001): Potential pitfails for the purchasing-power parity puzzle? Sampling and specification bias in mean reversion tests of the law of one price. Econometrica 69, 473-498.

Thisse, J.-F., Vives, X. (1988): On the Strategic Choice of Spatial Price Policy. American Economic Review 78, 122-137. 